\title{
A method to assess instream water quality - the role of nitrogen entries in a North German rural lowland catchment
}

\author{
B. Schmalz, K. Bieger, and N. Fohrer \\ Dept. Hydrology and Water Resources Management, Ecology Centre, Kiel Univ., Olshausenstr. 40, D-24098 Kiel, Germany
}

Received: 16 January 2008 - Revised: 26 March 2008 - Accepted: 28 May 2008 - Published: 20 June 2008

\begin{abstract}
The objective of this study was the detection and assessment of nutrient entry pathways in a complex mesoscale lowland catchment. The central aim was the development of a transferable method for an efficient estimation of instream water quality in rural environments. The investigated Kielstau catchment with a size of approximately $50 \mathrm{~km}^{2}$ is located in the North German lowlands. Land use is dominated by agriculture as well as pasture and is characterised by extensive artificial drainage systems. Additionally wastewater treatment plants influence the river water quality.

Six measuring campaigns were carried out over the period of one year. Each time, water quality was assessed at 16 locations along a $12 \mathrm{~km}$ longitudinal transect of the stream to consider the influence of each tributary or inflow. The results showed that the applied measuring method was useful to assess nutrient entry pathways into surface waters from diffuse and point sources. Some tributaries increased the main stream $\mathrm{NO}_{3}-\mathrm{N}$ concentrations especially in autumn. Using a German classification system (LAWA, 1998), the $\mathrm{NO}_{3}$ $\mathrm{N}$ results can mostly be assigned to water quality class III (heavily contaminated). Water balance and nitrate loads were modelled with the river basin scale model SWAT (Soil and Water Assessment Tool, Arnold et al., 1998). The measured and modelled discharges showed a good correlation. While nitrate load range and dynamics are well represented during the summer periods, they show a poor correlation during the winter period.
\end{abstract}

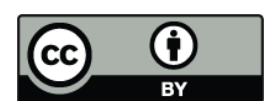

Correspondence to: B. Schmalz (bschmalz@hydrology.uni-kiel.de)

\section{Introduction}

Since December 2000, the integrated protection of all water bodies has been legally regulated for all European Union member states by the European Water Framework Directive (EC, 2000). Many rivers still do not reach a good status, which is aimed at for the year 2015. Concerning the chemical water quality the sources of poor quality and their pathways have to be detected. Tributaries can have a substantial influence on the nutrient balance of surface water bodies. Some tributaries can differ considerably from the main stream regarding the analysed parameters. According to Johnes and Burt (1993), obvious changes of nutrient concentrations and loads can occur downstream of tributaries and point sources. Lowland areas are characterised by a flat topography, low hydraulic gradients and near-surface groundwater. Drainage systems like tile drainage and open ditches change the natural water balance and influence the instream water quality due to a faster nutrient transport. Hooda et al. (1997) examined six small streams in agricultural catchment areas in Scotland and found that field drains or smaller ditches, despite having relatively high $\mathrm{NO}_{3}-\mathrm{N}$ concentrations, contributed small overall loadings and had either only short-range or no detectable impact on stream concentrations. David et al. (1997) detected high $\mathrm{NO}_{3}-\mathrm{N}$ concentrations within the range of 5 to $49 \mathrm{mg} / \mathrm{l}$ in drainage tiles in an agricultural catchment area in Illinois. In addition they found that during high flow events and intense precipitation the drainage systems have a substantial contribution to the $\mathrm{NO}_{3}-\mathrm{N}$ loss from agricultural fields.

The objective of this study was the assessment of nutrient entry pathways and the development of a transferable methodology for an efficient estimation of water quality in a complex hydrological lowland catchment. Measurement campaigns, concepts and analyses of the presented approach were adjusted to the demands of the European Water Framework Directive, especially in terms of sustainable river management. 


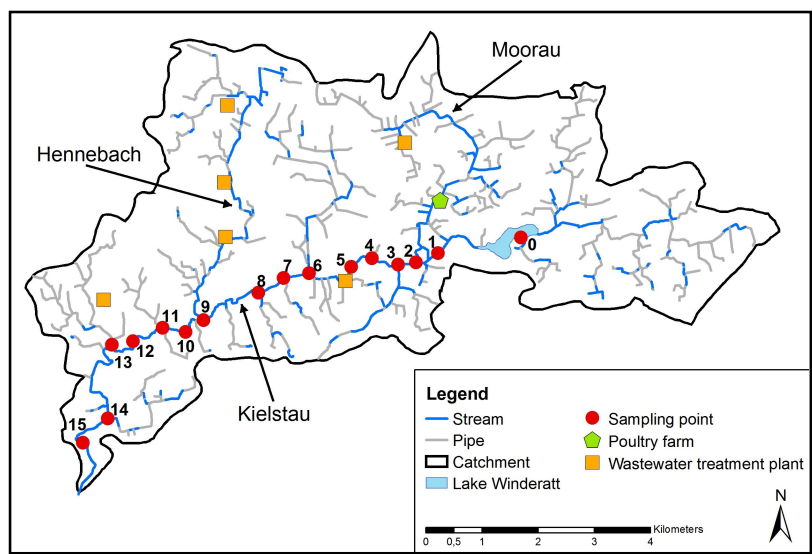

Fig. 1. Kielstau catchment (size: $50 \mathrm{~km}^{2}$ ), with tributaries and location of wastewater treatment plants, important farms, and sampling points.

\section{Investigation area}

The mesoscale investigation area "Kielstau catchment" is located in the lowland area of Schleswig-Holstein in Northern Germany. Sandy and loamy soils are characteristic for the catchment, with peat occurring along the streams. Land use is dominated by arable land and pasture. The maximum height difference is $49 \mathrm{~m}$. The precipitation is $841 \mathrm{~mm} / \mathrm{a}$ (station Satrup, 1961-1990, DWD, 2008) and the mean annual temperature $8.2^{\circ} \mathrm{C}$ (station Flensburg 1961-1990, DWD, 2008). The size of the Kielstau catchment (Fig. 1) is about $50 \mathrm{~km}^{2}$. The river Kielstau has a total length of $17 \mathrm{~km}$ and flows through the Lake Winderatt, which is surrounded by nature protection areas with moderate grazing. There are two important tributaries from the north, the Moorau and the Hennebach. In addition various smaller tributaries as well as drainage pipes and open ditches discharge into the Kielstau. The drained fraction of agricultural area in the Kielstau catchment is estimated to be $38 \%$ (Fohrer et al., 2007).

In the Kielstau catchment, nutrient entries from various farms in form of mineral fertiliser and manure application or animal husbandry in river vicinity as well as urban areas and a total of six wastewater treatment plants play an important role for the instream water quality (Schmalz et al., 2007). One wastewater treatment plant is situated at the beginning of the Moorau (3000 population equivalents), three are located along the Hennebach $(461,447$, and 240 population equivalents) and another two (1880 and 350 population equivalents) are discharging directly into the Kielstau (Fig. 1).

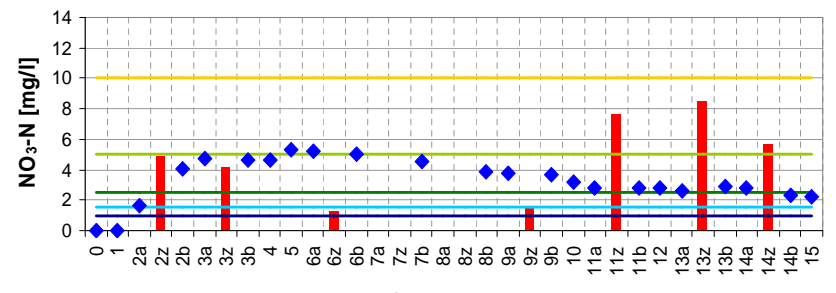

Sampling point

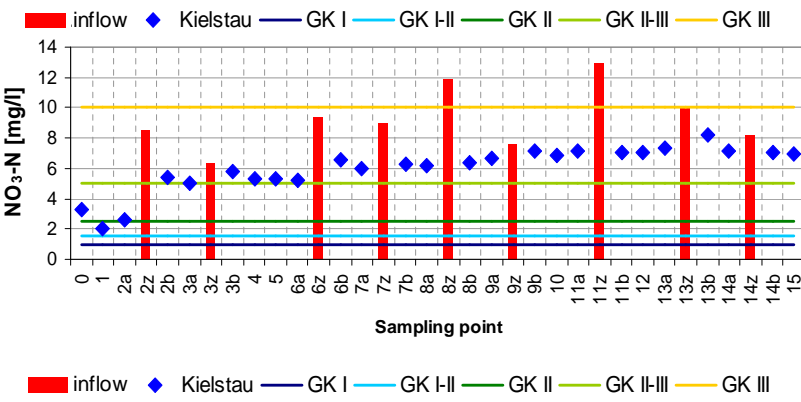

Fig. 2. Nitrate concentrations along the longitudinal river profile of the Kielstau with LAWA water quality classes $(\mathrm{GK})$ at 2 dates: (above) 19 July 2006 and (below) 15 November 2006. Sampling points situated upstream (a) and downstream (b) in the Kielstau as well as directly in the tributary $(\mathrm{z})$.

\section{Methods}

The water quality was measured at seven single points (no. 0 , $1,4,5,10,12,15$ ) and nine tributaries (ditches no. 3, 8, 14; drainage pipes no. $7,11,13$; tributaries no. $2,6,9$ ) along the longitudinal profile of the Kielstau during six campaigns from March 2006 to January 2007 (Fig. 1). The first sample was taken from the Lake Winderatt, the next sampling point was situated $700 \mathrm{~m}$ downstream of the lake outflow and the last one was located at the gauge Soltfeld at the catchment outlet (no. 15). Altogether a stream section of about $12 \mathrm{~km}$ was considered. At the confluence of tributaries the sampling took place upstream (a) and downstream (b) in the Kielstau as well as directly in the tributary (z; abbreviations used in Fig. 2). The nitrogen fractions $\mathrm{NH}_{4}-\mathrm{N}, \mathrm{NO}_{3}-\mathrm{N}$ and $\mathrm{N}_{\text {tot }}$ were analysed in the lab according to standard methods using photometry and ion chromatography. A general water quality classification was conducted using the "LAWA procedure for the chemical classification of water bodies" (LAWA, 1998). The LAWA is the German Working Group on water issues of the Federal States and the Federal Government. This system specifies water quality classes (Table 1) from I (unpolluted) to IV (excessively contaminated). Quality class II (moderately polluted) represents the target value for water quality until the year 2015 according to the European Water Framework Directive.

Additionally, an ecohydrological modelling exercise with the river basin model SWAT (Soil and Water Assessment Tool, Arnold et al., 1998, version 2005) was conducted to simulate the water balance and water quality in 
Table 1. Water quality classes for surface water bodies according to LAWA (1998) and their thresholds for $\mathrm{NH}_{4}-\mathrm{N}$ and $\mathrm{NO}_{3}-\mathrm{N}$.

\begin{tabular}{llll}
\hline Water quality class & Degree of degradation & $\mathrm{NH}_{4}-\mathrm{N}[\mathrm{mg} / \mathrm{l}]$ & $\mathrm{NO}_{3}-\mathrm{N}[\mathrm{mg} / \mathrm{l}]$ \\
\hline I & unpolluted or very lightly polluted & $\leq 0.04$ & $\leq 1$ \\
I-II & lightly polluted & $\leq 0.1$ & $\leq 1.5$ \\
II & moderately polluted & $\leq 0.3$ & $\leq 2.5$ \\
II-III & critically polluted & $\leq 0.6$ & $\leq 5$ \\
III- & heavily contaminated & $\leq 1.2$ & $\leq 10$ \\
III-IV & very heavily contaminated & $\leq 2.4$ & $\leq 20$ \\
IV & excessively contaminated & $>2.4$ & $>20$ \\
\hline
\end{tabular}

this complex hydrological catchment. SWAT is a semidistributed, process-oriented model for simulating water, nutrient and pesticide transport in mesoscale catchments. The catchment area is represented by subbasins and Hydrological Response Units (HRU; hydrotopes).

The Kielstau model is based on data collected during our own measuring campaigns and data provided by German authorities and institutions (see in detail in Tavares, 2006, Bieger, 2007):

- digital elevation model $25 \mathrm{~m} \times 25 \mathrm{~m}$ (LVermA, 1995),

- soil map 1:200000 (BGR, 1999),

- land use map $25 \mathrm{~m} \times 25 \mathrm{~m}$ (Deutsches Zentrum für Luftund Raumfahrt DLR, 1995),

- climate data (temperature, precipitation, wind speed, humidity) 1957-2006 (Deutscher Wetterdienst DWD, 2007),

- hourly discharge data of Kielstau at gauge Soltfeld (StUa Schleswig, 2007) 1984-2006

- sewage disposal data of 6 wastewater treatment plants (Kreis Schleswig-Flensburg, 2006).

The model runs covered the time period from November 1984 until October 2006. Due to lack of a longer measured time series the $\mathrm{NO}_{3}-\mathrm{N}$ modelling was conducted only for the period from June 2005 until October 2006. Simulations were run on a daily time step.

The catchment was divided into 8 subbasins and 117 HRUs. Wastewater treatment plants were implemented as point sources. Fertiliser inputs were taken into consideration by adjusting the management options for the land use classes. Arable land is implemented with two different crop rotations considering a) winter wheat-rape, and b) maize. Measured $\mathrm{NO}_{3}-\mathrm{N}$ concentrations (June 2005-October 2006 of Department of Hydrology and Water Resources Management of Ecology Centre at Kiel University, Tavares, 2006, Bieger, 2007) were used for estimation of the model efficiency (Nash and Sutcliffe, 1970).

\section{Nitrogen concentrations and loads}

4.1 Measured nitrogen concentrations along the river longitudinal profile

$\mathrm{NO}_{3}-\mathrm{N}$ concentrations at the beginning of the Kielstau downstream of the Lake Winderatt (no. 1) were relatively low, whereas the tributary Moorau (no. 2z) showed clearly elevated $\mathrm{NO}_{3}-\mathrm{N}$ values at all six measuring dates (Fig. 2). The $\mathrm{NH}_{4}-\mathrm{N}$ concentrations were also high in the Moorau and increased the Kielstau concentrations at all six dates. The water quality of the Moorau is strongly influenced by a wastewater treatment plant. Additionally a poultry farm in close proximity to the stream affects the water quality and storm water drains from a nearby village enter the stream through a pipe.

Considering the summer period, in July 2006, no further $\mathrm{NO}_{3}-\mathrm{N}$ concentration increase by tributaries was measured, because they were carrying little or no water or exhibited low nutrient concentrations. Along the river profile $\mathrm{NO}_{3}-\mathrm{N}$ concentrations decreased by dilution, denitrification and plant uptake (Fig. 2). Looking at the late autumn conditions, in November 2006, Tributaries no. 3, 6 and 13 caused an increase of the observed $\mathrm{NO}_{3}-\mathrm{N}$ values in the Kielstau, resulting in a slight increase of the values along the entire river profile (Fig. 2).

In six agricultural catchment areas in Scotland also Hooda et al. (1997) observed that nitrate stream concentrations were generally larger downstream compared with upstream, reflecting input from the farms. Seasonal variations of riverine export of nitrate from agricultural watersheds in Illinois were examined by Royer et al. (2006). They found that the majority of the annual $\mathrm{NO}_{3}-\mathrm{N}$ export occurred from mid-January through June across all monitored sites and years from 1994 to 2005 .

Using the LAWA classification, the $\mathrm{NO}_{3}-\mathrm{N}$ values (Kielstau without tributaries) can be categorized in the following water quality classes:

- mean of all 6 measurement campaigns: mostly III (range from II to III) 


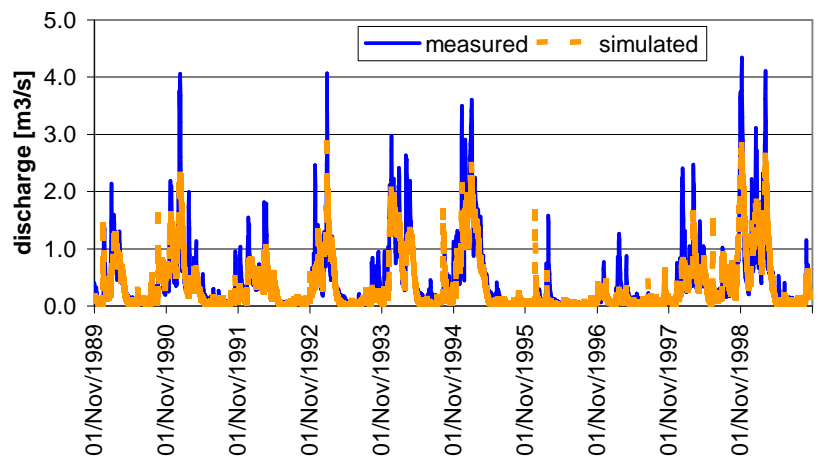

Fig. 3. Measured and modelled daily discharge at the Kielstau catchment outlet, gauge Soltfeld, during calibration period November 1989-October 1999 (Nash-Sutcliffe index is 0.73; coefficient of correlation is 0.86 ).

- in July 2006: mostly II-III (range from II to III) (Fig. 2)

- in November 2006: mostly III (range from II to III) (Fig. 2).

\subsection{Modelled nitrate loads}

Modelling the water balance with SWAT, the measured and modelled discharges showed a good correlation with a NashSutcliffe index of 0.73 during calibration period (November 1989-October 1999; Fig. 3) and 0.46 during validation period (November 1999-October 2006). The coefficient of correlation was 0.86 and 0.73 , respectively. The model setup and the calibration were based on implementing drainage, ponds and wetlands as well as on the adjustment of Curve Number values and specific groundwater parameters (Bieger, 2007). The results can be used to assess the amounts of discharge in the Kielstau area which is the base for load calculations.

Figure 4 shows the modelled daily $\mathrm{NO}_{3}-\mathrm{N}$ loads at the outlet of the catchment at gauge Soltfeld with the SWAT model. During the summer periods 2005 and 2006 the range as well as the general dynamic of the nitrate load were well represented by the model. In contrast, the $\mathrm{NO}_{3}-\mathrm{N}$ values during the winter period were represented poorly. This can be attributed to two reasons: Firstly, the discharge and, accordingly, the nitrate loads are underestimated by the model. Secondly, the higher $\mathrm{N}$ concentrations in winter, caused by $\mathrm{N}$ mobilisation from the catchment, are not represented in the model. The Nash-Sutcliffe index for the calibration period is 0.55 and the coefficient of correlation is 0.84 . Calibration was conducted by the nitrate percolation coefficient as well as by the rate factor for humus mineralization of active organic nutrients. Further calibration is required to improve the model performance. The period of existing measuring data is still too short for a model validation.

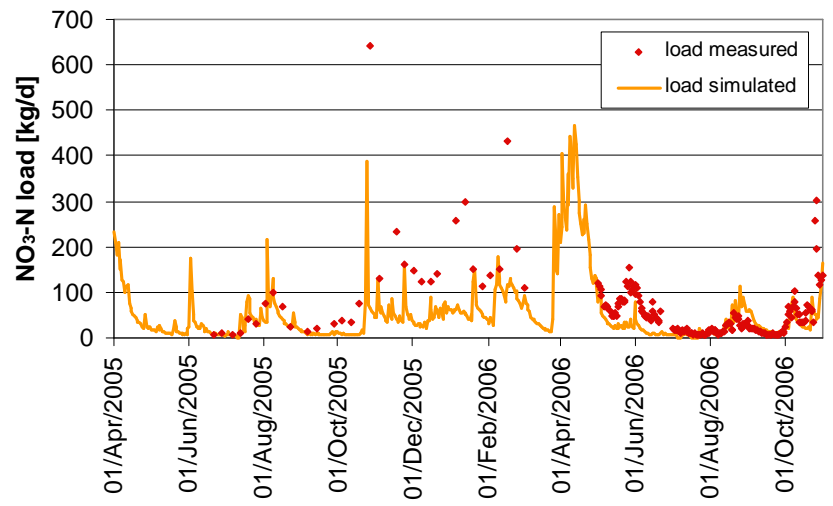

Fig. 4. Measured and modelled daily $\mathrm{NO}_{3}-\mathrm{N}$ loads at the Kielstau catchment outlet, gauge Soltfeld, during calibration period June 2005-October 2006 (Nash-Sutcliffe index is 0.55 ; coefficient of correlation is 0.84 ).

\section{Conclusions}

Nutrient entry pathways into surface waters from diffuse and point sources were assessed by measurements and an ecohydrological modelling. Inputs from agriculture as well as wastewater treatment plants were taken into account. We tested a measuring method to consider the totality of inflows like larger tributaries as well as smaller ditches or drain tiles. The strategy was successful by identifying the main inflows which contribute the largest concentrations. Using the Kielstau catchment as an example for a typical lowland catchment with mainly agricultural land use and a large fraction of drained fields, this method is transferable to other lowland catchments with a large fraction of drained agricultural areas.

The ecohydrological model SWAT was successfully used as a tool for the assessment of nutrient entry pathways under differentiation into point and diffuse sources. The agricultural entries into the river can be better quantified by considering different agricultural management practices. For this study we considered the current agricultural practices and sewage disposals to represent the current status. For a sustainable river basin management in terms of the European Water Framework Directive potential different management options can be tested as scenario runs with the implemented model. Using the knowledge of the measurement campaigns and applying SWAT as a management tool, future strategies can more easily be developed to improve the water quality mainly in some of the tributaries, e.g. the Moorau, in order to reach the desired water quality class II in the Kielstau.

Edited by: F. Portmann, K. Berkhoff, and M. Hunger

Reviewed by: two anonymous referees and the editors 


\section{References}

Arnold, J.-G., Srinivasan, R., Muttiah, R. S., and Williams, J. R.: Large area hydrologic modelling and assessment, Part I: Model development. Journal of the American Water Resources Association 34(1), 73-89, 1998.

BGR (Bundesanstalt für Geowissenschaften und Rohstoffe (Ed.)): Bodenübersichtskarte im Maßstab 1:200000, Verbreitung der Bodengesellschaften, Hannover, 1999.

Bieger, K.: Integrierte Analyse der Wasserqualität eines Fließgewässers im ländlich geprägten Raum des Norddeutschen Tieflands. Diplomarbeit im Fach Geographie, Ökologie-Zentrum Christian-Albrechts-Universität zu Kiel. p. 142, http://www.hydrology.uni-kiel.de/lehre/abschlussarbeiten/ 2008_kbieger_kielstauqualitaet.pdf, 2007.

David, M. B., Gentry, L. E., Kovacic, D. A., and Smith, K. M.: Nitrogen balance in and export from an agricultural watershed, J. Environ. Qual., 26(4), 1038-1048, 1997.

DLR (Deutsches Zentrum für Luft- und Raumfahrt): Landsat TM5Scene of 1995, upper left corner: RW: 3503180 HW: 6084975 , spatial resolution $25 \mathrm{~m} \times 25 \mathrm{~m}$, Köln, 1995 .

DWD (Deutscher Wetterdienst): Climate data 1957-2006, 2007.

DWD (Deutscher Wetterdienst): Means of precipitation and air temperature of the period 1961-1990, http://www.dwd.de/de/ FundE/Klima/KLIS/daten/online/nat/index_mittelwerte.htm, last access 3 Januar 2008, 2008.

EC: Directive 2000/60/EC of the European Parliament and of the Council of 23 October 2000 establishing a framework for the Community action in the field of water policy. Official Journal of the European Communities L 327/1. 2000.

Fohrer, N., Schmalz, B., Tavares, F., and Golon, J.: Ansätze zur Integration von landwirtschaftlichen Drainagen in die Modellierung des Landschaftswasserhaushalts von mesoskaligen Tieflandeinzugsgebieten. Hydrologie \& Wasserbewirtschaftung, 51(4), 164-169, 2007.
Hooda, P. S., Moynagh, M., Svoboda, I. F., Thurlow, M., Stewart, M., Thomson, M., and Anderson, H. A.: Streamwater nitrate concentrations in six agricultural catchments in Scotland. Science of the Total Environment, 201, 63-78, 1997.

Johnes, P. J. and Burt, T. P.: Nitrate in Surface Waters. In: Nitrate: Processes, Patterns and Management, edited by: Burt, T. P., Heathwaite, A. L., and Trudgill, S. T., John Wiley \& Sons Ltd., Chichester. 269-317, 1993.

Kreis Schleswig-Flensburg: Kläranlagen-Einleiterdaten, FD Wasserwirtschaft, Schleswig, 2006.

LAWA (Länderarbeitsgemeinschaft Wasser): Beurteilung der Wasserbeschaffenheit von Fließgewässern in der Bundesrepublik Deutschland - Chemische Gewässergüteklassifikation, Kulturbuchverlag Berlin, 1998.

LVermA (Landesvermessungsamt Schleswig-Holstein): Digitales Geländemodell für Schleswig-Holstein. Quelle: TK 25. Gitterweite $25 \mathrm{~m} \times 25 \mathrm{~m}$ und TK 50 Gitterweite $50 \mathrm{~m} \times 50 \mathrm{~m}$, Kiel, 1995.

Nash, J. E. and Sutcliffe, J. V.: River flow forecasting through conceptual models part I - A discussion of principles, J. Hydrol., 10(3), 282-290, 1970.

Royer, T. V., David, M. B., and Gentry, L. E.: Timing of riverine export of nitrate and phosphorus from agricultural watersheds in Illinois: Implications for reducing nutrient loading to the Mississippi River, Environ. Sci. Technol. 40, 4126-4131, 2006.

Schmalz, B., Tavares, F., and Fohrer, N.: Assessment of nutrient entry pathways and dominating hydrological processes in lowland catchments, Adv. Geosci., 11, 107-112, 2007, http://www.adv-geosci.net/11/107/2007/.

StUa Schleswig (Staatliches Umweltamt Schleswig): Hourly discharge data 1984-2006, 2007.

Tavares, F.: Continuous, spatially distributed, stream flow and quality assessment of a lowland catchment in Northern Germany. Master thesis in "Environmental Management", Ecology Centre Kiel University, p. 134, http://www.hydrology.uni-kiel.de/lehre/ abschlussarbeiten/msc_tavares.pdf, 2006. 